\title{
ADVERSE EFFECTS OF THE AUTOMOTIVE INDUSTRY ON CARBON DIOXIDE EMISSIONS
}

\author{
Mpho Bosupeng* \\ University of Botswana, Finance Graduate \\ P O Box 20151 Bontleng, Gaborone, Botswana
}

\begin{abstract}
:
This study aims to determine the effects of the automotive industry on carbon dioxide emissions for the period from 1997 to 2010 for diverse economies, as well as the relationships between carbon dioxide discharges and output. The study applies cointegration and causality tests to validate these associations. The results of the Johansen cointegration test depict long-run associations between the quantity of passenger cars and carbon dioxide emissions in France, Sweden, Spain, Hungary and Japan. In addition, significant relations were observed between output and carbon dioxide discharges in Spain, Canada, India and Japan. Changes in output had substantial impact on emissions in Germany, Canada and India. The results also show that the number of passenger cars influences the magnitude of emissions in multiple economies. In conclusion, the automotive industry has to be considered in policies that aim to reduce carbon dioxide emissions.
\end{abstract}

\section{Key words:}

carbon dioxide emissions, economic growth, automotive industry.

\section{INTRODUCTION}

The relationship between carbon dioxide emissions and economic growth has been an issue of concern for decades. Today, as the impact of excess carbon dioxide becomes more apparent, countries are inclined to reduce their emissions. An important task would be to alleviate carbon dioxide emissions regardless of whether the economy is advanced or not. China stepped forward by proposing a 40-45\% reduction in carbon dioxide emissions. The pressure of reducing carbon dioxide discharges is putting more pressure on China being the largest carbon dioxide emitter. However, that should not mean that the reduction of carbon dioxide emissions is China's burden. It is necessary that every country invests considerable effort since carbon dioxide effects are global rather than country-specific.

Chinese carbon dioxide emissions are fuelled by the automotive industry. According to $\mathrm{Xu}$ and Lin (2015), during the period 1980-2012, carbon dioxide emissions produced by the Chinese transport sector recorded a tenfold increase with an annual growth rate of $7.4 \%$. The authors highlighted that the number of passenger cars in China increased nearly eight times between 2000 and 2012. Comparatively, few studies have been conducted to determine the effects of carbon dioxide emissions from the automotive industry. 
The automotive industry produces carbon dioxide in two main ways. Firstly, during the vehicle manufacturing stage, industries produce carbon dioxide. Secondly, automobiles release carbon dioxide during the internal combustion of fuel. It is conceivable that the quantity of carbon dioxide emissions intensifies along with the increase in the number of cars manufactured.

Previous studies generally focused on determining associations between carbon dioxide emissions and economic growth. The effects of automotive industry on carbon dioxide discharges have not been addressed by the extant literature. The present study has several objectives. Firstly, it intends to investigate the relationships between carbon dioxide emissions and the quantity of passenger cars manufactured over the period from 1997 to 2010. Secondly, it aims to determine statistical affiliations between carbon dioxide discharges and economic growth. The investigation aims to fulfil these objectives by applying cointegration and causality tests. The remaining part of the paper is structured as follows. The first section presents an overview of previous studies. It is followed by a section elaborating on the methodology and empirical results, whereas the final part of the paper is dedicated to the analysis of research results and provision of relevant conclusions.

\section{LITERATURE REVIEW}

Multiple studies on economic growth and carbon dioxide emissions focused on China. This is because the Chinese economy is the largest emitter of carbon dioxide (Gregg et al., 2008). Logically, as an economy grows, the diversity of export multiplies, which further results in high carbon dioxide emissions. Alshehry and Belloumi (2015) investigated the dynamic relationships between energy consumption, energy price and economic activity in Saudi Arabia. The results indicate longterm associations between energy consumption, energy price, carbon dioxide emissions and economic growth. The authors have noted that energy consumption has significant effects on economic growth and carbon dioxide discharges. The study highlighted that strategies aimed at diminishing carbon dioxide discharges may not hinder Saudi Arabia's economic growth adversely. In addition, Lee and Brahmasrene (2013) investigated the influence of tourism on economic growth and carbon dioxide emissions in Europe from 1988 to 2009. The study showed that economic growth had significant impact on carbon dioxide emissions. Additionally, Wang (2013a) noted that output growth in China and the US is the mainstay of rising carbon dioxide emissions. The author highlighted that carbon dioxide discharges can be controlled by reducing energy intensity. This is conceivable especially if an economy uses fossil fuels such as coal as the main energy source. Omri (2013) used simultaneous-equations models to examine fourteen MENA countries over the period from 1990 to 2011. The results showed that energy consumption induces carbon dioxide emissions over the material period. Similarly, Zhang and Cheng (2009) proved that changes in carbon dioxide emissions depend on energy consumption.

Soytas and Sari (2009) explored causality between economic growth, carbon dioxide emissions and energy consumption in Turkey. The study proved that energy consumption was reliant on carbon dioxide emissions. The authors suggested that the lack of causation between income and emissions could mean that controls on carbon dioxide emissions may not impinge negatively on the economic growth. Most economies use green taxation as a measure against rising carbon dioxide discharges. Loganathan et al. (2014) examined the extent to which carbon taxation and economic growth affected the environment in Malaysia during the period from 1974 to 2010. Empirical evidence showed that carbon taxation and economic growth moved together in the long-run. The study registered causality effect from carbon taxes to carbon emissions with feedback. The effects of carbon taxes were further examined by Zhixin and Ya (2011). The study revealed that a carbon tax is a determinant factor of economic growth in the eastern part of China. 
In summary of the reviewed literature, the interactions between carbon dioxide discharges, energy consumption and economic growth have been thoroughly examined. Previous studies generally document a positive relationship between the trio (Alshehry \& Belloumi, 2015; Lee \& Brahmasrene, 2013; Wang, 2013a; Zhang \& Cheng, 2009; Soytas \& Sari 2009; Wang, 2012b). Numerous countries, including Malaysia and China, employ carbon taxation as the common measure to combat carbon dioxide emissions. In China, taxation was found to stimulate economic growth in some provinces (Zhixin \& Ya, 2011). This paper contributes to the literature by analysing twenty economies and determines the relationships between passenger cars manufactured, carbon dioxide emissions and GDP.

\section{MATERIALS AND METHODS}

This study examines the relationships between carbon dioxide emissions, GDP and the number of passenger cars. The data was obtained from The Global Economy (http://www.theglobaleconomy. com), which is a website committed to monitoring and disseminating macroeconomic data to researchers. National output was in US dollars (\$) while carbon dioxide emitted was measured in tonnes. The actual data was converted to natural logarithm values before proceeding with the investigation. Technically, it is easier to monitor the volatility of logarithmic values over time than actual data.This study covers the period from 1997 to 2010 with a majority of surveyed countries from Europe. Other continents, in particular America and Asia, were included to perform a more detailed comparative analysis. Due to data availability challenges, this study was restricted to data over the period from 1997 to 2010. Before proceeding with the investigation, it is imperative to carry out unit root tests. The Augmented Dickey-Fuller $(\mathrm{ADF})$ test is the most applied statistical test for determining the order of integration of macroeconomic time series. The model applied is:

$$
\Delta y_{t}=\alpha+\beta_{t}+\gamma y_{t-1}+\sum_{i=1}^{k} \delta_{i} \Delta y_{t-1}+\varepsilon_{t}
$$

The definition of terms is as follows. The term $\varepsilon_{t}$ is a pure white noise error term and $\Delta y_{\mathrm{t}-1}$ is equivalent to $y_{\mathrm{t}-1}-y_{\mathrm{t}-2}$. The data was tested for unit roots in first difference and the test equation included an intercept and trend. The results show that the data is non-stationary and suitable for further empirical analysis. Eviews 7 programme was used to compute the stationarity test. Based on the computed ADF test statistics, it is concluded that the data has unit roots at different levels ( $1 \%$, $5 \%$ and $10 \%$ levels). The results of the unit root test are presented in Table 1.

\section{The Johansen Cointegration Test}

The long-run affiliations between variables are usually determined by means of a cointegration test. For the purpose of this study, the Johansen cointegration test and the Saikkonen and Lütkepohl (2000) test will be applied to test for cointegrating vectors between GDP, carbon dioxide emissions and passenger cars. The advantage of cointegration tests is that they provide the longrun equilibrium relationships among the variables. The idea is that cointegrated variables would be attracted to each other, hence resulting in the longrun association following Johansen (1988). The use of cointegrated vectors was pioneered by Granger (1981), Granger and Weiss (1983), and Engle and Granger (1987). If there is cointegration between any two selected series, the Vector Error Correction (VECM) model may be represented as:

$$
\Delta X_{t}=\Pi X_{t-1}+\sum_{i=1}^{k-1} \Gamma_{i} \Delta X_{t-i}+e_{t}
$$

Define the terms as follows. Allow $\Pi$ to be a $m \times m$ matrix with long-run implications, $\Gamma$ a lag parameter matrix and $e_{t}$ and $m$-vector of residuals (Mallory \& Lence, 2012). Following Mallory and 


\begin{tabular}{|c|c|c|c|}
\hline \multicolumn{4}{|c|}{ Augmented Dickey-Fuller (ADF) test statistics } \\
\hline Country & $\mathrm{CO}_{2}$ & GDP & CARS \\
\hline Belgium & $-3.041318^{1,2,3}$ & $-3.249210^{1,2,3}$ & $-1.215140^{1,2,3}$ \\
\hline Germany & $-2.206577^{1,2,3}$ & $-3.234734^{1,2,3}$ & $-4.537655^{3}$ \\
\hline France & $-2.781334^{1,2,3}$ & $-3.292312^{1,2,3}$ & $-1.798264^{1,2,3}$ \\
\hline UK & $-1.934508^{1,2,3}$ & $-2.803161^{1,2,3}$ & $-3.081798^{1,2,3}$ \\
\hline Finland & $-2.543751^{1,2,3}$ & $-3.064896^{1,2,3}$ & $-3.560369^{3}$ \\
\hline Italy & $-0.581348^{1,2,3}$ & $-3.159121^{1,2,3}$ & $-3.199586^{1,2,3}$ \\
\hline Sweden & $-2.518799^{1,2,3}$ & $-2.785287^{1,2,3}$ & $-2.301638^{1,2,3}$ \\
\hline Spain & $1.104577^{1,2,3}$ & $-2.716076^{1,2,3}$ & $-1.722550^{1,2,3}$ \\
\hline Canada & $-0.959465^{1,2,3}$ & $-2.073849^{1,2,3}$ & $-2.425367^{1,2,3}$ \\
\hline China & $-2.593634^{1,2,3}$ & $-0.458977^{1,2,3}$ & $-3.131804^{1,2,3}$ \\
\hline India & $-1.999546^{1,2,3}$ & $-1.873736^{1,2,3}$ & $-4.846329^{3}$ \\
\hline Brazil & $-2.447626^{1,2,3}$ & $-1.646460^{1,2,3}$ & $5.740146^{1,2,3}$ \\
\hline Netherlands & $-2.307668^{1,2,3}$ & $-3.080269^{1,2,3}$ & $-2.830236^{1,2,3}$ \\
\hline Poland & $-3.028598^{1,2,3}$ & $-1.926700^{1,2,3}$ & $-2.619739^{1,2,3}$ \\
\hline Russia & $-0.374735^{1,2,3}$ & $-3.814554^{3}$ & $-3.630621^{1,2,3}$ \\
\hline Austria & $-1.430144^{1,2,3}$ & $-2.910486^{1,2,3}$ & $-1.270917^{1,2,3}$ \\
\hline Czech Republic & $-2.512794^{1,2,3}$ & $-3.063845^{1,2,3}$ & $-2.738640^{1,2,3}$ \\
\hline Hungary & $-2.000961^{1,2,3}$ & $-2.204526^{1,2,3}$ & $-3.332964^{1,2,3}$ \\
\hline USA & $-1.346614^{1,2,3}$ & $-3.636407^{2,3}$ & $-2.724039^{1,2,3}$ \\
\hline Japan & $-1.923877^{1,2,3}$ & $-0.006164^{1,2,3}$ & $-2.395700^{1,2,3}$ \\
\hline
\end{tabular}

The ADF test statistics are reported above. The critical values for cars and $\mathrm{CO}_{2}$ are as follows: -[4.8864266] is the critical value at $1 \%$ level; -[3.828975] is the critical value at 5\% level and -[3.362984] is the critical value at $10 \%$ level. Superscripts 1, 2, 3 indicate statistical significance at $1 \%, 5 \%$, and $10 \%$ critical levels. The critical values for GDP are as follows: - [4.992279] is the critical value at $1 \%$ level; - [3.875302] is the critical value at 5\% level and - [3.388330] is the critical value at 10\% level. The results are based on the model: $\Delta y_{t}=\alpha+\beta_{t}+\gamma y_{t-1}+\sum_{i=1}^{k} \delta_{i} \Delta y_{t-1}+\varepsilon_{t}$.

Eviews 7 was used to compute the ADF unit root test. The null hypothesis for the test is "series $\mathrm{x}$, has a unit root".

\section{Table 1. Augmented Dickey-Fuller (ADF) Test Results}

Lence (2012), the trace statistics and the maximum eigenvalue statistics will be used to test for cointegration. The null hypothesis for the trace test is that there are at most $r$ cointegrating vectors and will be computed as $-T \sum_{i=r+1}^{m} \ln \left(1-\lambda_{i}^{\prime}\right)$, where the term $T$ is the number of dates in the sample (Mallory \& Lence, 2012). The maximum-eigen value test will also be used to validate the null hypothesis that there are $r$ cointegrating vectors against the alternative of $r+1$. The model is $-T \ln \left(1-\lambda_{r+1}^{\prime}\right)$.

\section{Saikkonen and Lütkepohl Cointegration Approach}

Previous studies considered the Johansen methodology in the evaluation of the long-run relations. This paper further uses recent methodology proposed by Saikkonen and Lütkepohl (2000). The major difference between the Saikkonen and Lütkepohl (2000) test and the Johansen procedure is that under the Saikkonen and Lütkepohl (2000) approach, the estimation of the deterministic term 
is carried out first and then subtracted from the time series observations. Saikkonen and Lütkepohl (2000) considered a $\operatorname{VAR}(p)$ process of the form:

$$
\begin{aligned}
& y_{t}=v+A_{1} y_{t-1}+\cdots+A_{p} y_{t-p}+\varepsilon_{t} \\
& t=p+1, p+2, \ldots,
\end{aligned}
$$

The pioneers allowed $v$ to be an unknown $n \times 1$ intercept vector. The term $A_{j}$ is a $n \times n$ coefficient matrix while $\varepsilon_{t}$ was assigned to be a $n \times 1$ stochastic error term assumed to be a martingale difference sequence with $E\left(\varepsilon_{t} \mid \varepsilon_{s} s<t\right)=0$. The non-stochastic positive definite conditional covariance matrix was defined as $E\left(\varepsilon_{t} \grave{\varepsilon}_{t} \mid \varepsilon_{s, S}<t\right)=\Omega$. By subtracting $y_{t-1}$ on both sides of the above vector autoregressive process and rearranging the terms, the resulting error correction model will be as follows:

$$
\begin{aligned}
& \Delta \tilde{y}_{t}=v+\Pi \tilde{y}_{t-1}+\sum_{j=1}^{p-1} \Gamma_{j} \Delta \tilde{y}_{t-j}+\varepsilon_{t} \\
& t=p+1, p+2, \ldots,
\end{aligned}
$$

The definition of terms is $\Pi=-\left(I_{n}-A_{1}-\cdots-A_{p}\right)$ while $\Gamma_{j}=-\left(A_{j+1}+\cdots+A_{p}\right)(j=1, \ldots, p-1)$. The test validates if $H\left(r_{0}\right): r k(\Pi)=r_{0}$.

\section{Toda and Yamamoto Approach to Granger Causality}

The Granger causality test has been applied several times to validate causal relationships in economics. However, Granger causality is often based on the assumption that the variables are cointegrated. The Granger causality test has certain limitations. Firstly, if the variables under consideration are driven by the common third process with different lags, there is a possibility of failing to reject the alternative hypothesis of Granger causality. Additionally, Granger causality is more reliable if one is considering data with a wide span. Therefore, this study uses Toda and Yamamoto (1995) approach to Granger causality. Wolde-Rufael (2005) observed that the Toda and Yamamoto (1995) approach fits the standard vector autoregressive model in the levels of the variables. Consequently, this minimizes the risks associated with the likelihood of wrongly identifying the order of integration of the series (Mavrotas \& Kelly, 2001). This paper applies the Toda and Yamamoto (1995) approach as discussed by Wolde-Rufael (2005). The tests commenced by augmenting the correct VAR order $k$, by the maximal order of integration, $d_{\max }$ (Wolde-Rufael, 2005). Following Toda and Yamamoto (1995), once this operation is done, a $\left(k+d_{\max }\right)^{\text {th }}$ order of VAR is estimated and the coefficients of $d_{\text {max }}$ vector are ignored (Caporale \& Pittis, 1999; Rambaldi \& Doran, 1996; Rambaldi, 1997; Zapata \& Rambaldi, 1997). In order to implement the Toda and Yamamoto (1995) approach to Granger causality, the models are represented by the following VAR systems:

For Carbon dioxide and Passenger Cars

$$
\begin{aligned}
& C O_{2 t}=\alpha_{0}+\sum_{i=1}^{k} \alpha_{1 i} C O_{2 t-i}+\sum_{j=k+1}^{d_{\max }} \alpha_{2 j} C O_{2 t-j}+\sum_{i=1}^{k} \emptyset_{1 i} C A R S_{t-i}+\sum_{j=k+1}^{d_{\max }} \emptyset_{2 j} \operatorname{CARS}_{t-j}+\lambda_{1 t} \\
& \text { CARS }_{t}=\beta_{0}+\sum_{i=1}^{k} \beta_{1 i} \mathrm{CARS}_{t-1}+\sum_{j=k+1}^{d_{\max }} \beta_{2 j} C A R S_{t-j}+\sum_{i=1}^{k} \delta_{1 i} C O_{2 t-i}+\sum_{j=k+1}^{d_{\max }} \delta_{2 j} C O_{2 t-j}+\lambda_{2 t}
\end{aligned}
$$

For Carbon dioxide and GDP

$$
\begin{aligned}
& C O_{2 t}=\alpha_{0}+\sum_{i=1}^{k} \alpha_{1 i} C O_{2 t-i}+\sum_{j=k+1}^{d_{\max }} \alpha_{2 j} C O_{2 t-j}+\sum_{i=1}^{k} \emptyset_{1 i} G D P_{t-i}+\sum_{j=k+1}^{d_{\max }} \emptyset_{2 j} G D P_{t-j}+\lambda_{1 t} \\
& G D P_{t}=\beta_{0}+\sum_{i=1}^{k} \beta_{1 i} G D P_{t-1}+\sum_{j=k+1}^{d_{\max }} \beta_{2 j} G D P_{t-j}+\sum_{i=1}^{k} \delta_{1 i} C O_{2 t-i}+\sum_{j=k+1}^{d_{\max }} \delta_{2 j} C O_{2 t-j}+\lambda_{2 t}
\end{aligned}
$$




\section{EMPIRICAL RESULTS}

The Johansen cointegration test was carried out to determine long-term relations between the quantity of passenger cars and carbon dioxide emissions. Eviews 7 was used to compute the test at $5 \%$ significance level. The results of the test show that there is a long-run relationship between the number of passenger cars and carbon dioxide emissions in France, Sweden, Spain, Hungary and Japan. These economies registered $\rho$-values less than the critical level of $5 \%(\rho<0.05)$, thus implying co-integration between variables. The Johansen cointegration test was further applied to validate statistical relations between carbon dioxide emissions and GDP.The test showed that carbon dioxide discharges and GDP move together in the long-run in Spain, Canada, India and Japan. The $\rho$-values for these economies were less than the $5 \%$ significant level, thus implying long-term significant relationships between carbon dioxide emissions and GDP. Table 2 and Table 3 show the results of the Johansen cointegration test.

The Saikkonen and Lütkepohl (2000) cointegration test was carried out at 90\%, 95\% and 99\% critical levels using JMulti (4) statistical package. The results prove that there is a long-run relationship between dioxide emissions and the number of passenger cars manufactured in all of the countries. Note that $\rho$-values less than the critical levels of $90 \%, 95 \%$ and $99 \%$ represent cointegration. The Saikkonen and Lütkepohl (2000) test was further applied to verify long-term affiliations between GDP and carbon dioxide emissions. Similarly, the results prove that there are long-term relationships between carbon dioxide emissions and GDP for the surveyed economies. Table 4 and Table 5 present the results of the Saikkonen and Lütkepohl (2000) cointegration test.

Eviews 7 was used to carry out the Toda and Yamamoto (1995) approach to Granger causality. The Toda and Yamamoto (1995) technique for testing causality demonstrated that an increase in the number of passenger cars induces an up- surge in carbon dioxide emissions for the following economies: Belgium, France, India, China and Hungary. The reverse causality proved that the intensification of carbon dioxide emissions creates an increase in the quantity of cars manufactures in Belgium. Namely, it is the only country which exhibited causal relations with feedback between carbon dioxide emissions and cars manufactured (bidirectional causality). Note well that $\rho$-values less than the critical level of $5 \%$ represent causation from one variable to the other. The Toda and Yamamoto (1995) approach was further carried out to verify causal links between carbon dioxide emissions and GDP. The test affirmed that an escalation in carbon dioxide emissions induces economic growth in Belgium, China and Japan. Nonetheless, the reverse causality proved that economic growth is the leading indicator of carbon dioxide emissions in Germany, Canada and India. Table 6 and Table 7 present the results of the Toda and Yamamoto (1995) approach to Granger causality.

\section{DISCUSSION AND CONCLUSION}

This paper aimed to determine long-run relationships between carbon dioxide emissions, passenger cars and national output for twenty countries between 1997 and 2010. The study differs from other studies because it focused on the automotive industry as a contributor to the Greenhouse effect. Comparatively, most European economies are reputable automotive manufacturers, including Germany, France, Italy and Belgium. This study intended to find out how the automotive industry affects the production of carbon dioxide in multiple economies. The results of the Johansen cointegration test demonstrated that the number of passenger cars and carbon dioxide emissions move together in the long-run in France, Sweden, Spain, Hungary and Japan. Additionally, economic growth was associated with carbon dioxide emissions in Spain, Canada, India, Hungary and Japan. Furthermore, Spain and Japan revealed long-term 


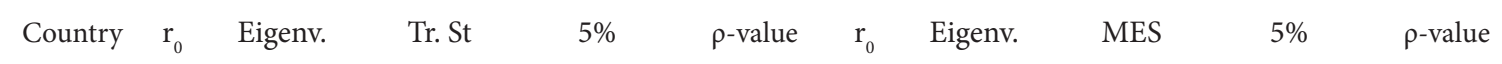

TRACE TEST

\begin{tabular}{|c|c|c|c|c|c|c|c|c|c|c|}
\hline \multirow[t]{2}{*}{ Belgium } & 0 & 0.520659 & 9.269670 & 15.49470 & 0.34100 & 0 & 0.520659 & 8.824106 & 14.26460 & 0.30110 \\
\hline & 1 & 0.036449 & 0.445564 & 3.84140 & 0.50440 & 1 & 0.036449 & 0.445564 & 3.84140 & 0.50440 \\
\hline \multirow[t]{2}{*}{ Germany } & 0 & 0.626510 & 14.974710 & 15.49470 & 0.05980 & 0 & 0.626510 & 11.8183800 & 14.26460 & 0.11770 \\
\hline & 1 & 0.231279 & 3.156326 & 3.84140 & 0.07560 & 1 & 0.231279 & 3.156326 & 3.84140 & 0.07560 \\
\hline \multirow[t]{2}{*}{ France } & 0 & 0.889659 & 31.354220 & 15.49470 & $0.00010^{* * *}$ & 0 & 0.889659 & 26.45017 & 14.26460 & $0.00040^{\star * *}$ \\
\hline & 1 & 0.335467 & 4.904051 & 3.84140 & $0.02680^{\star * *}$ & 1 & 0.335467 & 4.904051 & 3.84140 & $0.02680^{\star * *}$ \\
\hline \multirow[t]{2}{*}{ UK } & 0 & 0.537209 & 13.051010 & 15.49470 & 0.11300 & 0 & 0.537209 & 9.245768 & 14.26460 & 0.26630 \\
\hline & 1 & 0.271744 & 3.805240 & 3.84140 & 0.05110 & 1 & 0.271744 & 3.805240 & 3.84140 & 0.05110 \\
\hline \multirow[t]{2}{*}{ Finland } & 0 & 0.391294 & 6.828784 & 15.49470 & 0.59760 & 0 & 0.391294 & 5.957045 & 14.26460 & 0.61870 \\
\hline & 1 & 0.070069 & 0.871740 & 3.84140 & 0.35050 & 1 & 0.070069 & 0.871740 & 3.84140 & 0.35050 \\
\hline \multirow[t]{2}{*}{ Italy } & 0 & 0.182812 & 2.425771 & 15.49470 & 0.98690 & 0 & 0.182812 & 2.4222638 & 14.26460 & 0.97760 \\
\hline & 1 & 0.000261 & 0.003133 & 3.84140 & 0.95370 & 1 & 0.000261 & 0.003133 & 3.84140 & 0.95370 \\
\hline \multirow[t]{2}{*}{ Sweden } & 0 & 0.592585 & 16.708450 & 15.49470 & $0.03270^{\star * *}$ & 0 & 0.592585 & 10.77509 & 14.26460 & 0.16580 \\
\hline & 1 & 0.390092 & 5.933364 & 3.84140 & $0.01490^{\star * *}$ & 1 & 0.390092 & 5.933364 & 3.84140 & $0.01490^{\star * *}$ \\
\hline \multirow[t]{2}{*}{ Spain } & 0 & 0.486303 & 12.063050 & 15.49470 & 0.15930 & 0 & 0.486303 & 7.993462 & 14.26460 & 0.37940 \\
\hline & 1 & 0.287612 & 4.069583 & 3.84140 & $0.04370^{\star * *}$ & 1 & 0.287612 & 4.069583 & 3.84140 & $0.04370^{\star * *}$ \\
\hline \multirow[t]{2}{*}{ Canada } & 0 & 0.592021 & 12.50506 & 15.49470 & 0.13430 & 0 & 0.592021 & 10.75849 & 14.26460 & 0.16670 \\
\hline & 1 & 0.135451 & 1.746571 & 3.84140 & 0.18630 & 1 & 0.135451 & 1.7465751 & 3.84140 & 0.18830 \\
\hline \multirow[t]{2}{*}{ China } & 0 & 0.559551 & 10.000230 & 15.49470 & 0.28070 & 0 & 0.559551 & 9.839533 & 14.26460 & 0.22270 \\
\hline & 1 & 0.013302 & 0.160701 & 3.84140 & 0.68850 & 1 & 0.013302 & 0.160701 & 3.84140 & 0.68850 \\
\hline \multirow[t]{2}{*}{ India } & 0 & 0.489424 & 9.098862 & 15.49470 & 0.35630 & 0 & 0.489424 & 8.066581 & 14.26460 & 0.37200 \\
\hline & 1 & 0.082427 & 1.032282 & 3.84140 & 0.30960 & 1 & 0.082427 & 1.032282 & 3.84140 & 0.30960 \\
\hline \multirow[t]{2}{*}{ Brazil } & 0 & 0.314521 & 5.175994 & 15.49470 & 0.78990 & 0 & 0.314521 & 4.531645 & 14.26460 & 0.79940 \\
\hline & 1 & 0.052280 & 0.644349 & 3.84140 & 0.42210 & 1 & 0.052280 & 0.644349 & 3.84140 & 0.42210 \\
\hline \multirow[t]{2}{*}{ Netherlands } & 0 & 0.344930 & 5.401876 & 15.49470 & 0.76480 & 0 & 0.354930 & 5.2607650 & 14.26460 & 0.70860 \\
\hline & 1 & 0.011690 & 0.141110 & 3.84140 & 0.70720 & 1 & 0.011690 & 0.141110 & 3.84140 & 0.70720 \\
\hline \multirow[t]{2}{*}{ Poland } & 0 & 0.669084 & 14.52290 & 15.49470 & 0.06970 & 0 & 0.669084 & 13.27068 & 14.26460 & 0.07130 \\
\hline & 1 & 0.099091 & 1.252217 & 3.84140 & 0.26310 & 1 & 0.099091 & 1.2522170 & 3.84140 & 0.26310 \\
\hline \multirow[t]{2}{*}{ Russia } & 0 & 0.625557 & 11.796800 & 15.49470 & 0.16690 & 0 & 0.625557 & 11.787780 & 14.26460 & 0.11890 \\
\hline & 1 & 0.000752 & 0.009029 & 3.84140 & 0.92390 & 1 & 0.000752 & 0.009029 & 3.84140 & 0.92390 \\
\hline \multirow[t]{2}{*}{ Austria } & 0 & 0.514502 & 10.781930 & 15.49470 & 0.22530 & 0 & 0.514502 & 8.670966 & 14.26460 & 0.31460 \\
\hline & 1 & 0.161301 & 2.110960 & 3.84140 & 0.14620 & 1 & 0.161309 & 2.110960 & 3.84140 & 0.14620 \\
\hline \multirow[t]{2}{*}{ Czech } & 0 & 0.582923 & 10.502668 & 15.49470 & 0.21400 & 0 & 0.582923 & 10.49380 & 14.26460 & 0.18150 \\
\hline & 1 & 0.000739 & 0.008875 & 3.84140 & 0.92460 & 1 & 0.000739 & 0.008875 & 3.84140 & 0.92460 \\
\hline \multirow[t]{2}{*}{ Hungary } & 0 & 0.716404 & 16.337870 & 15.49470 & $0.03730^{* * *}$ & 0 & 0.716404 & 15.12247 & 14.26460 & $0.03650^{\star * *}$ \\
\hline & 1 & 0.096323 & 1.215399 & 3.84140 & 0.27030 & 1 & 0.096323 & 1.215399 & 3.84140 & 0.27030 \\
\hline \multirow[t]{2}{*}{ USA } & 0 & 0.368734 & 5.957053 & 15.49470 & 0.70060 & 0 & 0.368734 & 5.520236 & 14.26460 & 0.67520 \\
\hline & 1 & 0.035740 & 0.436727 & 3.84140 & 0.50870 & 1 & 0.035740 & 0.436727 & 3.84140 & 0.50870 \\
\hline \multirow[t]{2}{*}{ Japan } & 0 & 0.630308 & 16.664980 & 15.49470 & $0.03320^{* * *}$ & 0 & 0.630308 & 11.94102 & 14.26460 & 0.11290 \\
\hline & 1 & 0.225419 & 4.723961 & 3.84140 & $0.02970^{\star * *}$ & 1 & 0.325449 & 4.723961 & 3.84140 & $0.02970^{\star * *}$ \\
\hline
\end{tabular}

Note:

asterisks $\left.{ }^{* * *}\right)$ indicate statistical significance at $5 \%$ critical level. Note that $\rho$-values less than critical level of 5\% $(\rho<0.005)$ represent cointegration. The test was carried out using Eviews 7. 


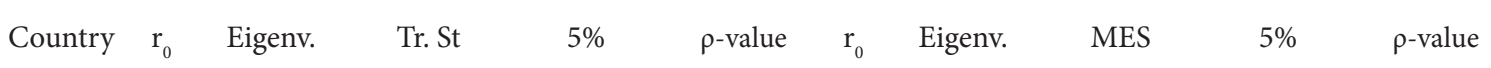

TRACE TEST

\begin{tabular}{|c|c|c|c|c|c|c|c|c|c|c|}
\hline Belgium & 0 & 0.601038 & 13.39120 & 15.49470 & 0.10120 & 0 & 0.601038 & 11.02666 & 14.26460 & 0.15290 \\
\hline & 1 & 0.178846 & 2.364542 & 3.84140 & 0.12410 & 1 & 0.178846 & 2.364542 & 3.84140 & 0.12410 \\
\hline \multirow[t]{2}{*}{ Germany } & 0 & 0.504522 & 8.69121 & 15.49470 & 0.39630 & 0 & 0.504522 & 8.426796 & 14.26460 & 0.33700 \\
\hline & 1 & 0.02112 & 0.268324 & 3.84140 & 0.60450 & 1 & 0.022112 & 0.268324 & 3.84140 & 0.60450 \\
\hline \multirow[t]{2}{*}{ France } & 0 & 0.561641 & 10.45165 & 15.49470 & 0.24760 & 0 & 0.561641 & 9.896602 & 14.26460 & 0.21880 \\
\hline & 1 & 0.045200 & 0.555046 & 3.84140 & 0.45630 & 1 & 0.045200 & 0.555046 & 3.84140 & 0.45630 \\
\hline \multirow[t]{2}{*}{ UK } & 0 & 0.422238 & 6.691162 & 15.49470 & 0.61380 & 0 & 0.422280 & 6.583111 & 14.26460 & 0.53960 \\
\hline & 1 & 0.008964 & 0.108050 & 3.84140 & 0.74240 & 1 & 0.008964 & 0.108050 & 3.84140 & 0.74240 \\
\hline \multirow[t]{2}{*}{ Finland } & 0 & 0.420909 & 6.568960 & 15.49470 & 0.61780 & 0 & 0.420909 & 6.555556 & 14.26460 & 0.54300 \\
\hline & 1 & 0.008409 & 0.101339 & 3.84140 & 0.75020 & 1 & 0.008409 & 0.101339 & 3.84140 & 0.75020 \\
\hline \multirow[t]{2}{*}{ Italy } & 0 & 0.486039 & 9.498669 & 15.49470 & 0.32130 & 0 & 0.486039 & 7.987288 & 14.26460 & 0.38000 \\
\hline & 1 & 0.118340 & 1.511381 & 3.84140 & 0.21890 & 1 & 0.118340 & 1.511381 & 3.84140 & 0.21890 \\
\hline \multirow[t]{2}{*}{ Sweden } & 0 & 0.439083 & 7.700004 & 15.49470 & 0.49800 & 0 & 0.439083 & 6.938198 & 14.26460 & 0.49650 \\
\hline & 1 & 0.061511 & 0.761806 & 3.84140 & 0.38280 & 1 & 0.061511 & 0.761806 & 3.84140 & 0.38280 \\
\hline \multirow[t]{2}{*}{ Spain } & 0 & 0.500937 & 14.82328 & 15.49470 & 0.06290 & 0 & 0.500937 & 8.346272 & 14.26460 & 0.34520 \\
\hline & 1 & 0.417398 & 6.483011 & 3.84140 & $0.01090^{\star * *}$ & 1 & 0.417398 & 6.483011 & 3.84140 & $0.01020^{\star \star *}$ \\
\hline \multirow[t]{2}{*}{ Canada } & 0 & 0.753951 & 16.85353 & 15.49470 & $0.03100^{* * *}$ & 0 & 0.753951 & 16.82670 & 14.26460 & $0.01920^{\star * *}$ \\
\hline & 1 & 0.002233 & 0.026827 & 3.84140 & 0.86980 & 1 & 0.002233 & 0.026827 & 3.84140 & 0.86980 \\
\hline \multirow[t]{2}{*}{ China } & 0 & 0.454334 & 7.817842 & 15.49470 & 0.48510 & 0 & 0.454334 & 7.268975 & 14.26460 & 0.45780 \\
\hline & 1 & 0.044709 & 0.548867 & 3.84140 & 0.45880 & 1 & 0.044709 & 0.548867 & 3.84140 & 0.45880 \\
\hline \multirow[t]{2}{*}{ India } & 0 & 0.779370 & 21.20512 & 15.49470 & $0.00620^{* * *}$ & 0 & 0.779370 & 18.135240 & 14.26460 & $0.01160^{* * *}$ \\
\hline & 1 & 0.225722 & 3.069884 & 3.84140 & 0.07980 & 1 & 0.225722 & 3.069884 & 3.84140 & 0.07980 \\
\hline \multirow[t]{2}{*}{ Brazil } & 0 & 0.644840 & 13.46020 & 15.49470 & 0.09900 & 0 & 0.644840 & 12.42225 & 14.26460 & 0.09580 \\
\hline & 1 & 0.082861 & 1.037951 & 3.84140 & 0.30830 & 1 & 0.082861 & 1.037951 & 3.84140 & 0.30830 \\
\hline \multirow[t]{2}{*}{ Netherlands } & 0 & 0.306479 & 4.732486 & 15.49470 & 0.83650 & 0 & 0.306479 & 4.391688 & 14.26460 & 0.81590 \\
\hline & 1 & 0.028000 & 0.340798 & 3.84140 & 0.55940 & 1 & 0.028008 & 0.340798 & 3.84140 & 0.55940 \\
\hline \multirow[t]{2}{*}{ Poland } & 0 & 0.637393 & 12.80174 & 15.49470 & 0.12230 & 0 & 0.639393 & 12.173230 & 14.26460 & 0.10430 \\
\hline & 1 & 0.051028 & 0.628509 & 3.84140 & 0.42790 & 1 & 0.051028 & 0.628509 & 3.84140 & 0.42790 \\
\hline \multirow[t]{2}{*}{ Russia } & 0 & 0.508096 & 9.373235 & 15.49470 & 0.33200 & 0 & 0.508096 & 8.513669 & 14.26460 & 0.32890 \\
\hline & 1 & 0.069125 & 0.859566 & 3.84140 & 0.35390 & 1 & 0.069125 & 0.859660 & 3.84140 & 0.35390 \\
\hline \multirow[t]{2}{*}{ Austria } & 0 & 0.336218 & 7.395344 & 15.49470 & 0.53210 & 0 & 0.336218 & 4.917612 & 14.26460 & 0.75220 \\
\hline & 1 & 0.186556 & 2.477732 & 3.84140 & 0.11550 & 1 & 0.186556 & 2.477732 & 3.84140 & 0.11550 \\
\hline \multirow[t]{2}{*}{ Czech } & 0 & 0.649598 & 12.65943 & 15.49470 & 0.12790 & 0 & 0.649559 & 12.584090 & 14.26460 & 0.09060 \\
\hline & 1 & 0.006258 & 0.075335 & 3.84140 & 0.78370 & 1 & 0.006258 & 0.075335 & 3.84140 & 0.78370 \\
\hline \multirow[t]{2}{*}{ Hungary } & 0 & 0.267015 & 4.029748 & 15.49470 & 0.90110 & 0 & 0.267015 & 3.725570 & 14.26460 & 0.88690 \\
\hline & 1 & 0.024880 & 0.302191 & 3.84140 & 0.58250 & 1 & 0.024868 & 0.302191 & 3.84140 & 0.58250 \\
\hline \multirow[t]{2}{*}{ USA } & 0 & 0.441410 & 7.263345 & 15.49470 & 0.54720 & 0 & 0.441410 & 6.988065 & 14.26460 & 0.40960 \\
\hline & 1 & 0.022679 & 0.275279 & 3.84140 & 0.59880 & 1 & 0.022629 & 0.275279 & 3.84140 & 0.59880 \\
\hline \multirow[t]{2}{*}{ Japan } & 0 & 0.647598 & 19.42928 & 15.49470 & $0.01210^{\star * *}$ & 0 & 0.647598 & 12.51580 & 14.26460 & 0.09280 \\
\hline & 1 & 0.437927 & 6.913480 & 3.84140 & $0.00860^{\star * *}$ & 1 & 0.437927 & 6.913480 & 3.84140 & $0.00860^{\star * *}$ \\
\hline
\end{tabular}

Note:

asterisks $\left(^{* * *}\right)$ indicate statistical significance at $5 \%$ critical level. Note that $\rho$-values less than critical level of $5 \%(\rho<0.005)$ represent cointegration. The test was carried out using Eviews 7. 


\begin{tabular}{|c|c|c|c|c|c|c|c|c|c|c|c|c|}
\hline Country & $\mathrm{r}_{0}$ & LR & $90 \%$ & $95 \%$ & $99 \%$ & $\rho$-value & $\mathrm{r}_{0}$ & LR & $90 \%$ & $95 \%$ & $99 \%$ & $\rho$-value \\
\hline Belgium & 0 & 12.8500 & 13.880 & 15.760 & 19.710 & $0.14220^{1,2,3}$ & 1 & 1.4000 & 5.470 & 6.790 & 9.730 & $0.68560^{1,2,3}$ \\
\hline Germany & 0 & 8.30000 & 13.880 & 15.760 & 19.710 & $0.51280^{1,2,3}$ & 1 & 1.0900 & 5.470 & 6.790 & 9.730 & $0.76880^{1,2,3}$ \\
\hline France & 0 & 15.0200 & 13.880 & 15.760 & 19.710 & $0.06620^{1,2,3}$ & 1 & 2.7000 & 5.470 & 6.790 & 9.730 & $0.39530^{1,2,3}$ \\
\hline UK & 0 & 13.4200 & 13.880 & 15.760 & 19.710 & $0.11720^{1,2,3}$ & 1 & 0.7800 & 5.470 & 6.790 & 9.730 & $0.85110^{1,2,3}$ \\
\hline Finland & 0 & 6.2300 & 13.880 & 15.760 & 19.710 & $0.74990^{1,2,3}$ & 1 & 5.5500 & 5.470 & 6.790 & 9.730 & $0.09610^{1,2,3}$ \\
\hline Italy & 0 & 13.8600 & 13.880 & 15.760 & 19.710 & $0.10080^{1,2,3}$ & 1 & 3.3400 & 5.470 & 6.790 & 9.730 & $0.29240^{1,2,3}$ \\
\hline Sweden & 0 & 12.2500 & 13.880 & 15.760 & 19.710 & $0.17350^{1,2,3}$ & 1 & 5.8200 & 5.470 & 6.790 & 9.730 & $0.08360^{1,2,3}$ \\
\hline Spain & 0 & 6.8300 & 13.880 & 15.760 & 19.710 & $0.68250^{1,2,3}$ & 1 & 0.8100 & 5.470 & 6.790 & 9.730 & $0.84200^{1,2,3}$ \\
\hline Canada & 0 & 3.1300 & 13.880 & 15.760 & 19.710 & $0.97740^{3}$ & 1 & 1.9900 & 5.470 & 6.790 & 9.730 & $0.54100^{1,2,3}$ \\
\hline China & 0 & 12.4900 & 13.880 & 15.760 & 19.710 & $0.16040^{1,2,3}$ & 1 & 2.5500 & 5.470 & 6.790 & 9.730 & $0.42320^{1,2,3}$ \\
\hline India & 0 & 8.0600 & 13.880 & 15.760 & 19.710 & $0.54040^{1,2,3}$ & 1 & 2.5800 & 5.470 & 6.790 & 9.730 & $0.41670^{1,2,3}$ \\
\hline Brazil & 0 & 8.7600 & 13.880 & 15.760 & 19.710 & $0.46190^{1,2,3}$ & 1 & 3.4500 & 5.470 & 6.790 & 9.730 & $0.27680^{1,2,3}$ \\
\hline Netherl. & 0 & 5.7300 & 13.880 & 15.760 & 19.710 & $0.80200^{1,2,3}$ & 1 & 2.1500 & 5.470 & 6.790 & 9.730 & $0.50510^{1,2,3}$ \\
\hline Poland & 0 & 11.4700 & 13.880 & 15.760 & 19.710 & $0.22150^{1,2,3}$ & 1 & 0.8600 & 5.470 & 6.790 & 9.730 & $0.83020^{1,2,3}$ \\
\hline Russia & 0 & 3.9300 & 13.880 & 15.760 & 19.710 & $0.94460^{2,3}$ & 1 & 2.1400 & 5.470 & 6.790 & 9.730 & $0.50580^{1,2,3}$ \\
\hline Austria & 0 & 7.1600 & 13.880 & 15.760 & 19.710 & $0.64480^{1,2,3}$ & 1 & 1.8600 & 5.470 & 6.790 & 9.730 & $0.57110^{1,2,3}$ \\
\hline Czech. & 0 & 13.6300 & 13.880 & 15.760 & 19.710 & $0.10910^{1,2,3}$ & 1 & 2.2800 & 5.470 & 6.790 & 9.730 & $0.47580^{1,2,3}$ \\
\hline Hungary & 0 & 8.3200 & 13.880 & 15.760 & 19.710 & $0.51030^{1,2,3}$ & 1 & 3.7600 & 5.470 & 6.790 & 9.730 & $0.23810^{1,2,3}$ \\
\hline USA & 0 & 7.4400 & 13.880 & 15.760 & 19.710 & $0.61200^{1,2,3}$ & 1 & 1.1800 & 5.470 & 6.790 & 9.730 & $0.74420^{1,2,3}$ \\
\hline Japan & 0 & 6.3400 & 13.880 & 15.760 & 19.710 & $0.73830^{1,2,3}$ & 1 & 1.0400 & 5.470 & 6.790 & 9.730 & $0.78160^{1,2,3}$ \\
\hline
\end{tabular}

Note: ${ }^{1}$ shows statistical significance at $90 \%$ critical level; ${ }^{2}$ shows statistical significance at $95 \%$ critical level; ${ }^{3}$ shows statistical significance at $99 \%$ critical level. Note that $\rho$-values less than critical levels of $90 \%, 95 \%$ and $99 \%$ represent cointegration. The test was carried out using JMulti 4 statistical package. The deterministic term of the VECM was defined as $D_{t}=u_{o}+u_{1 t^{*}}$ Abbreviations Nether and Czech stand for Netherlands and Czechoslovakia. LR is the likelihood ratio.

Table 4. Saikkonen and Lütkepohl Cointegration Test Results (Cars and Carbon Dioxide emissions)

\begin{tabular}{|c|c|c|c|c|c|c|c|c|c|c|c|c|}
\hline Country & $\mathrm{r}_{0}$ & LR & $90 \%$ & $95 \%$ & $99 \%$ & $\rho$-value & $\mathrm{r}_{0}$ & LR & $90 \%$ & $95 \%$ & $99 \%$ & $\rho$-value \\
\hline Belgium & 0 & 7.9800 & 13.880 & 15.760 & 19.710 & $0.54900^{1,2,3}$ & 1 & 3.6400 & 5.470 & 6.790 & 9.730 & $0.25350^{1,2,3}$ \\
\hline Germany & 0 & 8.4200 & 13.880 & 15.760 & 19.710 & $0.50010^{1,2,3}$ & 1 & 2.2600 & 5.470 & 6.790 & 9.730 & $0.48070^{1,2,3}$ \\
\hline France & 0 & 10.0300 & 13.880 & 15.760 & 19.710 & $0.35540^{1,2,3}$ & 1 & 3.6900 & 5.470 & 6.790 & 9.730 & $0.24630^{1,2,3}$ \\
\hline UK & 0 & 9.2700 & 13.880 & 15.760 & 19.710 & $0.40890^{1,2,3}$ & 1 & 2.0200 & 5.470 & 6.790 & 9.730 & $0.53350^{1,2,3}$ \\
\hline Finland & 0 & 11.2900 & 13.880 & 15.760 & 19.710 & $0.23410^{1,2,3}$ & 1 & 3.1400 & 5.470 & 6.790 & 9.730 & $0.32180^{1,2,3}$ \\
\hline Italy & 0 & 8.2400 & 13.880 & 15.760 & 19.710 & $0.51970^{1,2,3}$ & 1 & 5.2200 & 5.470 & 6.790 & 9.730 & $0.11390^{1,2,3}$ \\
\hline Sweden & 0 & 10.7400 & 13.880 & 15.760 & 19.710 & $0.27550^{1,2,3}$ & 1 & 1.2300 & 5.470 & 6.790 & 9.730 & $0.73170^{1,2,3}$ \\
\hline Spain & 0 & 8.5900 & 13.880 & 15.760 & 19.710 & $0.48110^{1,2,3}$ & 1 & 3.0300 & 5.470 & 6.790 & 9.730 & $0.33810^{1,2,3}$ \\
\hline Canada & 0 & 9.4400 & 13.880 & 15.760 & 19.710 & $0.32910^{1,2,3}$ & 1 & 1.0800 & 5.470 & 6.790 & 9.730 & $0.77120^{1,2,3}$ \\
\hline China & 0 & 7.8100 & 13.880 & 15.760 & 19.710 & $0.56940^{1,2,3}$ & 1 & 0.0000 & 5.470 & 6.790 & 9.730 & 1.0000 \\
\hline India & 0 & 17.3400 & 13.880 & 15.760 & 19.710 & $0.02680^{1,2,3}$ & 1 & & 5.470 & 6.790 & 9.730 & $0.96180^{3}$ \\
\hline Brazil & 0 & 13.6700 & 13.880 & 15.760 & 19.710 & $0.10740^{1,2,3}$ & 1 & 5.4700 & 5.470 & 6.790 & 9.730 & $0.09040^{1,2,3}$ \\
\hline Nether. & 0 & 6.0700 & 13.880 & 15.760 & 19.710 & $0.76660^{1,2,3}$ & 1 & 1.9600 & 5.470 & 6.790 & 9.730 & $0.54650^{1,2,3}$ \\
\hline Poland & 0 & 5.3300 & 13.880 & 15.760 & 19.710 & $0.08414^{1,2,3}$ & 1 & 0.6400 & 5.470 & 6.790 & 9.730 & $0.88720^{1,2,3}$ \\
\hline Russia & 0 & 6.7400 & 13.880 & 15.760 & 19.710 & $0.69260^{1,2,3}$ & 1 & & 5.470 & 6.790 & 9.730 & $0.50830^{1,2,3}$ \\
\hline Austria & 0 & 10.2800 & 13.880 & 15.760 & 19.710 & $0.31300^{1,2,3}$ & 1 & 0.1600 & 5.470 & 6.790 & 9.730 & $0.98680^{3}$ \\
\hline Czech & 0 & 13.1600 & 13.880 & 15.760 & 19.710 & $0.12840^{1,2,3}$ & 1 & 2.6100 & 5.470 & 6.790 & 9.730 & $0.41090^{1,2,3}$ \\
\hline Hungary & 0 & 7.4100 & 13.880 & 15.760 & 19.710 & $0.61580^{1,2,3}$ & 1 & 0.0400 & 5.470 & 6.790 & 9.730 & 0.99860 \\
\hline USA & 0 & 7.7800 & 13.880 & 15.760 & 19.710 & $0.57270^{1,2,3}$ & 1 & 0.4700 & 5.470 & 6.790 & 9.730 & $0.92830^{2,3}$ \\
\hline Japan & 0 & 25.9300 & 13.880 & 15.760 & 19.710 & $0.00060^{1,2,3}$ & 1 & 0.9500 & 5.470 & 6.790 & 9.730 & $0.80600^{1,2,3}$ \\
\hline
\end{tabular}

Note: ${ }^{1}$ shows statistical significance at $90 \%$ critical level; ${ }^{2}$ shows statistical significance at $95 \%$ critical level; ${ }^{3}$ shows statistical significance at $99 \%$ critical level. Note that $\rho$-values less than critical levels of $90 \%, 95 \%$ and $99 \%$ represent cointegration. The test was carried out using JMulti 4 statistical package. The deterministic term of the VECM was defined as $\mathrm{D}_{\mathrm{t}}=\mathrm{u}_{\mathrm{o}}+\mathrm{u}_{1 \mathrm{t}}$. Abbreviations Nether and Czech stand for Netherlands and Czechoslovakia. LR is the likelihood ratio. 


\begin{tabular}{|c|c|c|c|c|c|}
\hline \multirow{2}{*}{ Country } & \multicolumn{2}{|c|}{$\mathrm{CARS}_{\mathrm{t}} \Rightarrow \mathrm{CO}_{2 \mathrm{t}}$} & \multicolumn{2}{|c|}{$\mathrm{CO}_{2 \mathrm{t}} \Rightarrow \mathrm{CARS}_{\mathrm{t}}$} & \multirow{2}{*}{$\begin{array}{c}\text { Direction of } \\
\text { Causality }\end{array}$} \\
\hline & Chi-sqr. & $\rho$-value & Chi-sqr. & $\rho$-value & \\
\hline Belgium & 59.104717 & $0.00000^{\star * *}$ & 8.154584 & $0.01700^{* * *}$ & $\mathrm{CARS} \Leftrightarrow \mathrm{CO}_{2}$ \\
\hline Germany & 2.286682 & 0.31880 & 4.311314 & 0.11580 & $\mathrm{CARS} \Leftrightarrow \mathrm{CO}_{2}$ \\
\hline France & 28.47141 & $0.00000^{* * *}$ & 2.125093 & 0.34560 & $\mathrm{CARS} \Rightarrow \mathrm{CO}_{2}$ \\
\hline UK & 2.376341 & 0.30480 & 4.154422 & 0.12530 & $\mathrm{CARS} \Leftrightarrow \mathrm{CO}_{2}$ \\
\hline Finland & 1.657083 & 0.43670 & 0.887466 & 0.64160 & $\mathrm{CARS} \Leftrightarrow \mathrm{CO}_{2}$ \\
\hline Italy & 1.889531 & 0.38880 & 0.080626 & 0.96050 & $\mathrm{CARS} \Leftrightarrow \mathrm{CO}_{2}$ \\
\hline Sweden & 3.611615 & 0.16430 & 4.703694 & 0.09520 & $\mathrm{CARS} \Leftrightarrow \mathrm{CO}_{2}$ \\
\hline Spain & 0.612189 & 0.73630 & 2.582503 & 0.24020 & $\mathrm{CARS} \Leftrightarrow \mathrm{CO}_{2}$ \\
\hline Canada & 5.383014 & 0.06780 & 2.763328 & 0.25120 & $\mathrm{CARS} \Leftrightarrow \mathrm{CO}_{2}$ \\
\hline China & 13.06314 & $0.00150^{\star * *}$ & 1.673646 & 0.43310 & $\mathrm{CARS} \Rightarrow \mathrm{CO}_{2}$ \\
\hline India & 7.145049 & $0.02810^{* * *}$ & 1.466626 & 0.48030 & $\mathrm{CARS} \Rightarrow \mathrm{CO}_{2}$ \\
\hline Brazil & 1.732384 & 0.42050 & 0.766385 & 0.68170 & $\mathrm{CARS} \Leftrightarrow \mathrm{CO}_{2}$ \\
\hline Netherlands & 2.562627 & 0.27770 & 1.062775 & 0.58780 & $\mathrm{CARS} \Leftrightarrow \mathrm{CO}_{2}$ \\
\hline Poland & 0.599871 & 0.74090 & 1.137335 & 0.56630 & $\mathrm{CARS} \Leftrightarrow \mathrm{CO}_{2}$ \\
\hline Russia & 1.909065 & 0.38500 & 2.764507 & 0.25100 & $\mathrm{CARS} \Leftrightarrow \mathrm{CO}_{2}$ \\
\hline Austria & 1.230388 & 0.54050 & 3.980084 & 0.13670 & $\mathrm{CARS} \Leftrightarrow \mathrm{CO}_{2}$ \\
\hline Czech Rep. & 3.930151 & 0.14010 & 1.309898 & 0.51950 & $\mathrm{CARS} \Leftrightarrow \mathrm{CO}_{2}$ \\
\hline Hungary & 21.48232 & $0.00000^{\star * *}$ & 2.007782 & 0.36650 & $\mathrm{CARS} \Rightarrow \mathrm{CO}_{2}$ \\
\hline USA & 0.398679 & 0.81930 & 1.248914 & 0.53560 & $\mathrm{CARS} \Leftrightarrow \mathrm{CO}_{2}$ \\
\hline Japan & 3.792453 & 0.15010 & 1.958584 & 0.37560 & $\mathrm{CARS} \Leftrightarrow \mathrm{CO}_{2}$ \\
\hline
\end{tabular}

Note: $\Rightarrow$ implies causality in a given direction; $\Leftrightarrow$ implies a bidirectional causal relationship; $\Leftrightarrow$ implies that there is no causality between the variables. The test was carried out at $5 \%$ significant level. The null hypothesis $\left(\mathrm{H}_{\mathrm{o}}\right)$ is that a given variable does not Granger cause the other (non-causality). Note that $\rho$-values less than the $5 \%$ critical level $(\rho<0.05)$ represent causality in a given direction. The null hypothesis is therefore rejected for $\rho$-values less than the significant level. Asterisks ${ }^{* * *}$ ) represent a causal relationship at the 5\% significant level. Eviews (7) was used to carry out the Toda-Yamamoto approach to Granger causality.

\section{Table 6. Carbon Dioxide Emissions and Passenger Cars Causality Test Results}

\begin{tabular}{|c|c|c|c|c|c|}
\hline \multirow{2}{*}{ Country } & \multicolumn{2}{|c|}{$\mathrm{CO}_{2 \mathrm{t}} \Rightarrow \mathrm{GDP}_{\mathrm{t}}$} & \multicolumn{2}{|c|}{$\mathrm{GDP}_{\mathrm{t}} \Rightarrow \mathrm{CO}_{2 \mathrm{t}}$} & \multirow{2}{*}{$\begin{array}{c}\text { Direction of } \\
\text { Causality }\end{array}$} \\
\hline & Chi-sqr. & $\rho$-value & Chi-sqr. & $\rho$-value & \\
\hline Belgium & 5.997179 & $0.04990^{* * *}$ & 1.381841 & 0.50110 & $\mathrm{CO}_{2} \Rightarrow \mathrm{GDP}$ \\
\hline Germany & 1.574460 & 0.45510 & 8.216851 & $0.016440^{* * *}$ & $\mathrm{GDP} \Rightarrow \mathrm{CO}_{2}$ \\
\hline France & 0.339628 & 0.84380 & 3.728085 & 0.15500 & $\mathrm{CO}_{2} \Leftrightarrow \mathrm{GDP}$ \\
\hline UK & 0.569202 & 0.75230 & 5.540013 & 0.06270 & $\mathrm{CO}_{2} \Leftrightarrow \mathrm{GDP}$ \\
\hline Finland & 5.071794 & 0.07920 & 0.0943402 & 0.95440 & $\mathrm{CO}_{2} \Leftrightarrow \mathrm{GDP}$ \\
\hline Italy & 1.564736 & 0.45730 & 5.655870 & 0.05910 & $\mathrm{CO}_{2} \Leftrightarrow \mathrm{GDP}$ \\
\hline Sweden & 0.319497 & 0.85240 & 5.006456 & 0.08180 & $\mathrm{CO}_{2} \nRightarrow \mathrm{GDP}$ \\
\hline Spain & 5.273626 & 0.07160 & 2.167275 & 0.33840 & $\mathrm{CO}_{2} \nRightarrow \mathrm{GDP}$ \\
\hline Canada & 0.079894 & 0.96080 & 8.409318 & $0.01490^{* * *}$ & $\mathrm{GDP} \Rightarrow \mathrm{CO}_{2}$ \\
\hline India & 1.226891 & 0.54150 & 30.289190 & $0.00000^{* * *}$ & $\mathrm{GDP} \Rightarrow \mathrm{CO}_{2}$ \\
\hline China & 6.021857 & $0.04920^{* * *}$ & 2.518846 & 0.28380 & $\mathrm{CO}_{2} \Rightarrow \mathrm{GDP}$ \\
\hline Brazil & 4.706173 & 0.09510 & 5.269573 & 0.07170 & $\mathrm{CO}_{2} \nRightarrow \mathrm{GDP}$ \\
\hline Netherlands & 0.364179 & 0.83350 & 2.061637 & 0.35670 & $\mathrm{CO}_{2} \nRightarrow \mathrm{GDP}$ \\
\hline Poland & 1.7954444 & 0.40750 & 1.298403 & 0.52250 & $\mathrm{CO}_{2} \Leftrightarrow \mathrm{GDP}$ \\
\hline Russia & 0.991433 & 0.60910 & 2.854952 & 0.23990 & $\mathrm{CO}_{2} \Leftrightarrow \mathrm{GDP}$ \\
\hline Austria & 1.220388 & 0.54050 & 3.980004 & 0.13670 & $\mathrm{CO}_{2} \nRightarrow \mathrm{GDP}$ \\
\hline Czech Rep. & 3.158509 & 0.20610 & 4.514860 & 0.10320 & $\mathrm{CO}_{2} \Leftrightarrow \mathrm{GDP}$ \\
\hline Hungary & 1.267756 & 0.53050 & 2.220213 & 0.32950 & $\mathrm{CO}_{2} \Leftrightarrow \mathrm{GDP}$ \\
\hline USA & 1.425651 & 0.49030 & 2.020224 & 0.36420 & $\mathrm{CO}_{2} \nRightarrow \mathrm{GDP}$ \\
\hline Japan & 9.956343 & $0.00690^{* * *}$ & 2.257205 & 0.32350 & $\mathrm{CO}_{2} \Rightarrow \mathrm{GDP}$ \\
\hline
\end{tabular}

Note: $\Rightarrow$ implies causality in a given direction; $\Leftrightarrow$ implies a bidirectional causal relationship; $\Leftrightarrow$ implies that there is no causality between the variables. The test was carried out at $5 \%$ significant level. The null hypothesis $\left(\mathrm{H}_{\mathrm{o}}\right)$ is that a given variable does not Granger cause the other (non-causality). Note that $\rho$-values less than the $5 \%$ critical level $(\rho<0.05)$ represent causality in a given direction. The null hypothesis is therefore rejected for $\rho$-values less than the significant level. Asterisks ( ${ }^{* * *}$ ) represent a causal relationship at the 5\% significant level. Eviews (7) was used to carry out the Toda-Yamamoto approach to Granger causality. 
relationships between the number of passenger cars and carbon dioxide discharges, as well as economic growth and carbon dioxide emissions. However, the Saikkonen and Lütkepohl (2000) test showed that changes in carbon dioxide emissions were associated with variations in the number of passenger cars for all of the surveyed economies. This was the same for the relationship between economic growth and carbon dioxide emissions. The Toda and Yamamoto (1995) causality test showed causality effect running from carbon dioxide emissions to GDP in Belgium, China and Japan. The reverse causality, however, revealed that variations in carbon dioxide emissions were brought by changes in national output in the case of Germany, Canada and India. The causality results also revealed that alterations in carbon dioxide emissions were influenced by the number of passenger cars in Belgium, France, India, China and Hungary. Carbon dioxide emissions seemed to be the leading indicator of the number of passenger cars in Belgium. The long-run relationship between carbon dioxide discharges and economic growth has been affirmed by previous studies such as Alshehry and Belloumi (2015), Lee and Brahmasrene (2013), and Omri (2013).

The results of this study carry some implications. The long-run relationship between carbon dioxide emissions and the number of cars is not ideal if we are heading towards low carbon emissions. For instance, if the number of cars is associated with carbon dioxide emissions in France, Belgium, India, China and Hungary, it may imply that such economies need to produce cars that are more environment-friendly. In China, the numbers of passenger cars proved to have significant effects on carbon dioxide emissions. The results are conceivable since $\mathrm{Xu}$ and Lin (2015) stated that the number of passenger cars in China increased nearly eight times between 2000 and 2012. This escalated carbon dioxide emissions in China. Catalytic converters are obsolete because their function is to convert poisonous gases from the combustion process into those more friendly such as carbon dioxide. In this way, more carbon dioxide will still be produced.

Most countries aim to reduce carbon dioxide emissions to a reasonable extent. China set a target of $40-45 \%$ reduction in emissions by 2025 . Deng et al. (2015) recommended that countries should reuse carbon dioxide with absorption and desorption technology. The captured gas can be used to manufacture other exportable products such as calcium carbonate $\left(\mathrm{CaCO}_{3}\right)$. Some economies including China and Malaysia use green taxation in their attempts to alleviate carbon dioxide emissions. In conclusion to this study, the automotive industry has substantial impact on carbon dioxide emissions and national output. Economies need to reduce carbon dioxide emissions and find alternative ways that do not impinge negatively on the overall economic growth.

\section{REFERENCES}

Alshehry, A.S., \& Belloumi, M. (2015). Energy consumption, carbon dioxide emissions and economic growth: The case of Saudi Arabia. Renewable and Sustainable Energy Reviews, 41, 237-247. doi:10.1016/j.rser.2014.08.004.

Deng, W., Chen, D.C., Huang, M., Hu, J., \& Chen, L. (2015). Carbon dioxide deliming in leather production: A literature review. Journal of Cleaner Production, 87, 26-38.

Engle, R.F., \& Granger, C.W.J. (1987). Co-Integration and Error Correction: Representation, Estimation, and Testing. Econometrica, 55(2), 251-276. doi:10.2307/1913236.

Granger, C.W.J., Huang, B.N., \& Yang, C.W. (2000). A bivariate causality between stock prices and exchange rates: evidence from recent Asian flu. The Quarterly Review of Economics and Finance, 40, 337-354.

Granger, C.J. (1981). Some properties of time series data and their use in econometric model specification. Journal of Econometrics, 55, 251-276. doi:10.1016/0304-4076(81)90079-8.

Granger, C.W.J. (1969). Investigating Causal Relations by Econometric Models and Cross-spectral Methods. Econometrica, 37(3), 424-438. doi:10.2307/1912791. 
Granger, C.W.J., \& Weiss, A.A. (1983). Time series analysis of error correction models. In S. Karlim, T. Amemiya, \& L.A. Goodman (Eds.), Studies in Economic Time Series and Multivariate Statistics. New York: Academic Press. doi:10.1016/b978-012-398750-1.50018-8.

Gregg, J.S., Andre, R.J., \& Marland, G. (2008). China: Emissions pattern of the world leader in $\mathrm{CO} 2$ emissions from fossil fuels consumption and cement production. Geophysical Research Letters 04/2008; 35(8). doi:10.1029/2007GL032887.

Huang, G., Xialing, O., \& Yao, X. (2015). Dynamics of China's regional carbon emission under gradient economic development trade. Ecological Indicators, 51, 197-204.

Jafari, Y., Othman, J., \& Nor Abu, H.S.M. (2012). Energy consumption, economic growth and environmental pollutants in Indonesia. Journal of Policy Modeling, 34, 879-889.

Johansen, S. (1988). Statistical analysis of cointegration vectors. Journal of Economic Dynamics and Control, 12, 231-254. doi:10.1016/0165-1889(88)90041-3.

Lee, J.W., \& Brahmasrene, T. (2013). Investigating the influence of tourism on economic growth and carbon emissions: evidence from panel analysis of the European Union. Tourism Management, 38, 69-76.

Loganathan, N., Shabaz, M., \& Taha, R. (2014). The link between green taxation and economic growth on $\mathrm{CO} 2$ emissions: fresh evidence from Malaysia. Renewable and Sustainable Energy Review, 38, 1083-1091.

Mallory, M., \& Lence, S.H. (2012). Testing for cointegration in the presence of moving average errors. Journal of Time Series Econometrics, 4, 1-66. doi:10.1515/1941-1928.1124.
Omri, A. (2013). CO2 emissions, energy consumption and economic growth in MENA countries: Evidence from simultaneous equation models. Energy Economics, 40, 657-664.

Saikkonen, P., \& Lütkepohl, H. (2000). Testing for the cointegrating rank of a VAR process with an intercept. Economic Theory, 16, 373-406.

Soytas, U., \& Sari, R. (2009). Energy consumption, economic growth, and carbon emissions: challenges faced by an EU candidate member. Ecological Economics, 68, 1667-1675.

Wang, C. (2013). Differential output growth across regions and carbon dioxide emissions: Evidence from U. S. and China. Energy, 53(C), 230-236.

Wang, K.M. (2012). Modelling the nonlinear relationship between $\mathrm{CO} 2$ emissions from oil and economic growth. Economic Modelling, 29(5), 1537-1547. doi:10.1016/j.econmod.2012.05.001.

Wang, Y., \& Liang, S. (2013). Carbon dioxide mitigation target of China in 2020 and key economic sectors. Energy Policy, 58, 90-96.

Zhang, X.P., \& Cheng, X.M. (2009). Energy consumption, carbon emissions and economic growth in China. Ecological Economics, 68, 2706-2712. doi:10.1016/j.ecolecon.2009.05.011.

Zhixin, Z., \& Ya, L. (2011). The impact of carbon dioxide on economic growth in China. Energy Procedia, 5, 1757-1761.

\section{NEGATIVNI EFEKTI AUTOMOBILSKE INDUSTRIJE NA EMISIJE UGLJEN-DIOKSIDA}

\section{Rezime:}

Ovaj rad ima za cilj da ispita uticaj automobilske industrije na emisije ugljen-dioksida u nekoliko zemalja u periodu od 1997-2010., kao i odnose između emisija ugljen-dioksida i ekonomskog razvoja pomenutih zemalja. U tu svrhu korišćeni su testovi uzročnosti i kointegracione analize. Rezultati Johansenove kointegracione analize ukazuju na dugoročnu vezu između broja putničkih automobila i emisija ugljen-dioksida u Francuskoj, Španiji, Švedskoj, Mađarskoj i Japanu. Takođe, primetna je i veza između ekonomskog rasta (proizvodnje) i emisija ugljen-dioksida u Španiji, Kanadi, Indiji i Japanu. Promene u ekonomskom razvoju su u velikoj meri uticale na emisije u Nemačkoj, Kanadi i Indiji. Rezultati takođe pokazuju da broj putničkih automobila utiče na obim emisija u brojnim zemljama. Stoga je neophodno pozabaviti se pitanjem automobilske industrije u okvirima politika koje imaju za cilj smanjenje emisija ugljen-dioskida.

\section{Ključne reči:}

emisije ugljen-dioksida, ekonomski razvoj, automobilska industrija. 